\title{
Pendidikan dan Pembangunan dalam Periode Tinggal Landas
}

\author{
Oleh : Boediono
}

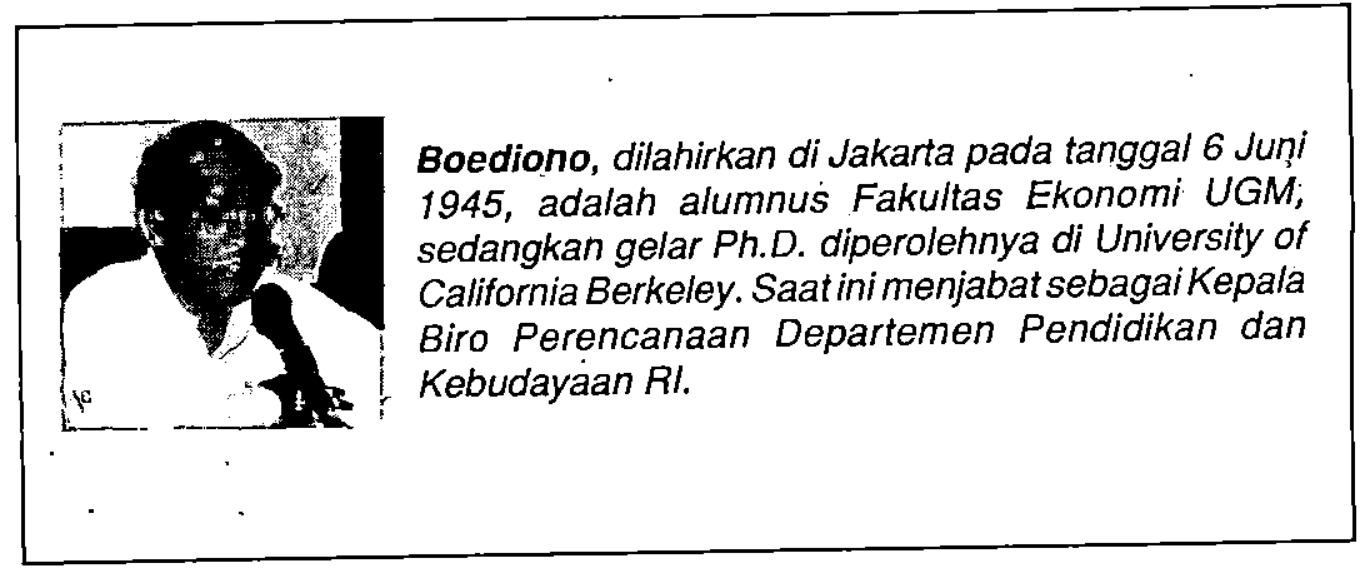

Pendahuluan

Tahun ini adalah tahun terakhir dari periode Pelita V, dan sekaligus merupakan tahun terakhir dari era Pembangunan Jangka Panjang 25 Tahun Pertama, yang telah dimulai sejak tahun 1969/70. Tahun depan merupakan awal dari periode Pelita VI dạn merupakan juga awal dari era Pembangunan Jangka Panjang 25 Tahun Kedua yang ditandai dengan periode "tinggal landas". Berbagai pernyataan, tulisan, maupun hasil diskusi menyatakan bahwa pembangunan sumber daya manusia mendapat perhatian khusus dalam periode tinggal landas.

Pembangunan pendidikan seringkali dipandang semata-mata sebagai suatu gejala penawaran atau supply phenomena di mana persoalan pokoknya terpusat pada bagaimanamenghasilkanlulusan sebanyakbanyaknya dan bagaimana meningkatkan mutu pendidikan itu sendiri. Dalam kenyataannya, pembangunan pendidikan itu merupakan suatu gejala permintaan atau demand phenomena di mana persoalan utamanya adalah untuk apa lulusan dihasilkan atau untuk apa mutu pendidikan itu ditingkatkan. Tentu saja kedua pandangan tersebut secara ideal harus dipertimbangkan secara simultan. Meskipun demikian, setiap tahap pembangunan pendidikan memerlukan tema atau tekanan sendiri-sendiri yaitu sesuai dengán lingkungan yang dituntut pada masing-masing tahap pembangunan ekonomi khususnya dan pembangunan nasional umumnya.

Pembangunan pendidikan dewasa ini agaknya dipandang sebagai gejala permintaan atau demand phenomena yang lebih mempersoalkan segi manfaat. 'Sesungguhnyalah bahwa pembangunan pendidikan, dalam jangka menengah dan jangka panjang, tidak dapat dilepaskan dari lingkungan pembangunan nasional di mana proses pendidikan itu sendiri tumbuh dan dibesarkan:

Mengingat investasi pendidikan 
merupakan investasi jangka panjang, maka pelaksanaan pembangunan pendidikan memerlukan semacam ideologi. Ideologi yang melandasi pembangunan pendidikan, yang selama ini seringkali digunakan, seperti diamanatkan dalam Pembukaan UUD 1945, yaitu "... mencerdaskan kehidupan bangsa ...". Oleh karena itu perwujudan amanat tersebut lebih berorientasi pada peningkatan mutu pendidikan.

Cuplikan tersebutmerupakan bagian dari amanat yang lebih utuh. Amanat utuh kiranya dapat digunakan sebagai ideologi dalam pembangunan pendidikan di masa depan adalah "... memajukan kesejahteraan umum, mencerdaskan kehidupan bangsa, dan ikut melaksanakan ketertiban dunia ...". Dengan demikian arah pembangunan pendidikan dalam jangka panjang mencakup bukan hanya peningkatan mutu yang mencerminkan amanat "...mencerdaskan kehidupan bangsa...", melainkanmencakupjuga peningkatan taraf hidup yang mencerminkan amanat "...memajukankesejahteraanumum...",dan membangun pendidikan sesuai dengan perkembangan iptek yang mencerminkan amanat "...ikut melaksanakan ketertiban dunia...". Dengan demikian, pembangunan pendidikan bukan hanya diorientasikan pada peningkatan mutu pendidikan, melainkan juga peningkatan taraf hidup sejalan dengan kemajuan ilmu pengetahuan dan teknologi.

Secara ringkas, pembangunan pendidikan dewasa ini dan menjelang masa depan agaknya perlu dipandang sebagai suatu gejala permintaan atau demand phenomena yang berorientasi pada aspek manfaat, dan investasinya kiranya perlu dilandaskan pada semacam ideologi perwujudan amanat Pembukaan UUD 1945 yang utuh. Makalah ini, oleh karena itu, membahas tentang pembangunan pendidikan, sebagai salah satu faktor dalam pembangunan sumberdaya manusia, dalam kaitannyadengan pembangunan khususnya dalam periode "tinggal landas" yaitu era yang akan kita masuki di masa depan.

\section{Kependudukan}

Kependudukan merupakan sisi penyediaan(supply) dari proses pendidikan yaitu input dari mana kegiatan pendidikan itu berpangkal. Dari sisi penyediaan pendidikan atau segi kependudukan tumbuh kelompok penduduk usia yang merupakan gelombang-gelombang anak didik yang akan melanda sistem pendidikan yang berlangsung dari satu periode waktu ke periode berikutnya." Tingkah laku dari gelombang-gelombang anak didik itu harus diwaspadai secara cermat dalam pengamatan dan analisis pembangunan pendidikan dalam janga panjang, karena gelombang-gelombang anak didik tersebut akan timbul secara teratur dan berurutan.

Jumlah penduduk akan meningkat dari 180,4 juta pada tahun 1990 ; menjadi 210,3 juta pada tahun 2000 , dan menjadi 253,7 juta pada tahun 2020, dengan pertambahan yang semakin menurun. ${ }^{2)}$ Angka pertumbuhan penduduk di Indonesia telah menurun dengan cepat sejak awal tahun Pelita. Angka pertumbuhan penduduk sebesar 1,64 persen pada tahun 1990-1995,

1) Jumlah murid yang pertama kali melanda atau masuk tingkat 1 sekolah dasar, dalam jangka panjang, dapat diamati sebagai suatu "gelombang" yang bergerak dari suatu waktu.ke waktu yang lain.

2) Aris Ananta dan Evi Nurvidya Arifin, Projection of Indonesian Population : 1990 - 2020, Demographie Institute, Population Projection Series No. 2, January 1991, Jakarta. 
diperkirakan akan menurun sehingga menjadi 1,04 persen pada tahun 2005-2010, dan akan menurun lagi menjadi 0,66 persen pada 2015-2020. Angka kelahirannya diperkirakan akan menurun juga dari 24,6 pada tahun 1990-1995 menjadi 18,0 pada tahun 2005-2010, dan turun lagi menjadi 14,6 pada tahun 2015-2020. Sedangkan angka kematiannya akan juga menurun dari 8,3 pada tahun 1990-1995, menjadi 7,6 pada tahun 2005-2010, dan akan menurun lagi menjadi 7,9 pada tahun 2015-2020. Menurunnya angka-angka tersebut sejak awal Pelitasecara cepat telah menyebabkan demografislebih awal di Indonesiadaripada di negara-negara berkembanglainnya yang memerlukan waktu lebih lama lagi.

Angka ketergantungan (depèndency ratio) yang menurijukkan anggota keluarga yang tergantung pada kepala keluarga (bread winner) diperkirakan akan menurun dari 66,15 persenpada tahun 1990 , menjadi 63,6 pada tahun 2000 , dan turunlagimenjadi 41,5 pada tahun 2020. Angka ketergantungan ini menunjukkan bahwa dalam masa depan akan semakin banyak kepala keluarga yang bekerja sehingga semakin kecil anggota yang tergantung kepadanya.

Tingkat urbanisasi (rate of urbanization) yang menunjukkan perbandingan jumlah penduduk yang bermukim di kota terhadapmereka yang di desa menunjukkan kecenderungan yang semakin meningkat. Dengan demikian mereka yang bermukim di kota akan bertambah semakin banyak. Tingkaturbanisasi sebesar28,79 pada tahun 1990 , diperkirakan akan meningkatmenjadi 36,46 pada tahun 2000 , dan diperkirakan akan menurun lagi menjadi 52,22 pada tahun 2020.

Struktur penduduk di masa depan akan berubah. Penduduk usia di bawah 20 tahun, pada tahun 1990, kiranya merupakan jumlah yang paling besar dibandingkan dengan usia-usia lainnya. Pada tahun 2005, strukturpenduduktersebutagaknyaberubah menjadi lebih tua, karena jumlah yang paling besar adalah mereka yang berusia 30 tahun ke bawah. Selanjutnya, pada tahun 2020, struktur penduduk akan berubah bertambah tua, karena jumlah penduduk terbesar adalah mereka yang berusia 40 tahun ke bawah. Dengan perkataan lain, strukturpenduduk yang sekarang berbentuk piramida yaitu lebih banyak usia muda, akan berubah menjadi stupa yaitu semakin lebih tua di masa mendatang (lihat Gambar Struktur Penduduk).

Kompisisi penduduk kelompok usia sekolah akan mengalami suatu gejala perubahän. Penduduk kelompok usia 7-12 tahun akan semakin berkurang yaitu sekitar 26,0 juta pada tahun 1990 , mencapai kejenuhan pada sekitar jumlah 25,0 juta pada tahun 1995, dan selanjutnya akan secara berangsur menurun perlahan (level off). Penduduk kelompok usia 13-15 tahun berjumlah 12,8 juta pada tahun 1990 akan meningkatmenjadi sejumlah 12,9 juta pada tahun 1995, kemudian menujukkan gejala menurun hingga mencapai sekitar 12,6 juta pada tahun 2020, dan menurun lagi menjadi 12,1 juta pada tahun 2020. Penduduk kelompokusia 16-18 tahun akan meningkat terus dari sejumlah 10,5 juta pada tahun 1990 menjadi 12,6 juta pada tahun 2015 , dan kemudian akan menurun menjadi 12,3 juta pada awal tahun 2020. Penduduk kelompokusia 19-24 tahun akan meningkat dari sejumlah 20,6 juta pada tahun 1990, menjadi 25,6 juta pada tahun 2000 , akan tetapi menurunmenjadi 24,7 juta pada tahun 2020. Dengan perkataan lain, jumlah 
penduduk kelompok usia sekolah dasar 712 tahun akan segera menunjukkan titik jenuhnya pada tahun 1995, sedangkan kelompok usia 13-15 tahun akan mencapai titik baliknya pada tahun 2005, mereka kelompok usia 16-18 tahun akan mulai menunjukkan tanda-tanda menurun pada awal tahun 2020, dan kelompok usia 19-24 tahun akan mulai menunjukkan gejala menurun pada tahun 2020.

Secara ringkas, jumlah penduduk akan semakin bertambah tetapi dengan tingkat pertambahan yang semakin menurun. Angka ketergantungan akan semakin menurun, menunjukkan semakin berkurangnya mereka yang tergantung kepada kepala keluarga atau meningkatnya, jumlah mereka yang bekerja. Tingkat urbanisasinya akan semăkin meningkat, sehingga semula seperempat dari penduduk bermukim menjadi setengahdari penduduk bermukim di kota. Dengan demikian, permasalahan pembangunan akan terpusat pada daerah pedesaan yang semakin berkurang penduduknya dan daerah perkotaan yang semakin bertambah penghuninya. Struktur penduduk di masa depan akan berubah sifatnya dari lebih banyak usia muda menjadi lebih banyak usia tua. Perubahan struktur penduduk ini mempengaruhi jumlah peserta didik. Gelombang anak didik sekolah dasar akan semakin menurun, sedangkan gelombang sekolah lanjutan pertama dan atas akan meningkat pada awalnya kemudian akan menurun. Gelombang pendidikan tinggi akanmenurun menjelang akhir tahun 2020 .

\section{Pergeseran Struktur Ekonomi dan Perubahan Alokasi Tenaga Kerja.}

Pada tahap awal pertumbuhan ekonomi hampir semua negara tidak hanya mempunyai satu sektor ekonomi; melainkan dva. Boeke mengamati adanya dualisme dalam perekonomian Indonesia pada zaman kolonial. Pertumbuhan ekonomi berjầlan sangat lambat, atau hampir tidak tumbuh, karena sektor tradisional feodal dan sektor modern kapitalis hidup secara. berdampingan dengantidaksałling pengaruh mempengaruhi. ${ }^{3)}$

Dualisme ekonomi ini dilihat juga oleh ekonomi dari aliran "klasik", Arthur Lewis. Dalam suatu ekonomi dengan "tenaga kerja yang tidak terbatas", Lewis menandai adanya re-alokasi tenaga kerja dari sektor pertanian subsisten (untuk memenuhi kebutuhan sendiri) ke sektor kapitalis (atau dalam pengertian ini adalah sektor industri).4) Selanjutnya dikemukakan bahwa pertumbuhan ekonomi akan berlangsung apabila surplus yang dibentuk ${ }^{i}$ oleh sektorkapitalis ditanam kembali dalam perekonomian. ") Re-alokasi tenaga kerja

3) Burger menyebut dua sistem ekonomi sosial "pra-kapitalisme" dan "kapitalisme tinggi". Lihat J.H. Boeke danD.H. Burger, Ekonomi Dualistis Dialog Antara Boeke dan' Burger, Bhratara, Yogyakarta 1973. Buku ini berisi pidato J.H. Boeke dalam pengukuhan guru besar luar biasa dalam ilmu ekonomi kolonial-tropis pada Universitas Leiden pada tanggal 15 Januari 1930 dengan judul Dualistische Economie, serta tulisan D.H. Burger dengan judul "Boeke's Dualisme" yang terbit dalam Indonesie, tahun ke-7, 1954, halaman 177-198.

4) Lihat Cris Manning dan Tadjuddin Noer Effendi, Urbanisasi, Pengangguran, dan Sektor Informaldi Kota, cetakankedua Yayasan PenerbitObor, Jakarta, 1990.

5) Lihat Arthur Lewis, "Economic Development with Unlimited Supply of Labour", The Manchester School, nomor 22, May, 1954. Lihat juga makalah penulis yang sama, "Futher Notes:Unlimited Supply of Labour", The Manchesier School, Januari, 1958. Makalah ini merupakan bahan pertimbangan utama atas diterimakannya Hadiah Nobel dalam nmu Ekonomi pada tahun 1987. 
berlangsung karena tingkat upah di sektor pertanian subsisten lebih rendah daripada' tingkat upah di sektor kapitalis.

Kuznets secara empiris mengadakan pengkajianterhadap perubahan-perubahan yang terjadi dalam pembangunan dan hasil pengkajiannya kemudian dikenal sebagai sintesa pertumbuhan ekonomi modem.? Pengkajian Kuznets tersebut dilanjutkan oleh Chenery dan Syrquin berdasarkan data dari 111 negara menggunakan analisa ekonometrik. Mereka antara lain menganalisa hubungan antara pertumbuhan dan perubahan struktur ekonomi. Temuan mereka sama dengan temuan Kuznets yaitu semakin tinggi GNP, peranan sektor pertanian di dalam output dan kesempatan kerja semakin menurun, sebaliknya peranan sektor industri dan jasa semakin 'meningkat."

Menurut Chenery, pada saat GNP per kapita sangat rendah (di bawah $\$ 100$ ), peranan sektor pertanian sangat dominan karena menyumbang lebih dari 50 persen, sedangkan sektor industri dan jasa masingmasing hanya sekitar 10 dan 30 persen, sisanya sebesar 10 persen adalah sektor lain-lain. Pada saat GNP per kapita meningkat, peranan sektor pertanian semakin menurunsementaraperanan kedua sektoryang lain semakinmeningkat. Ketika GNP per kapita mencapai $\$ 1000$, peranan pertanian semakin mengecil, hanya sekitar 12 persen; sedangkan peranan sektor industri dan jasa masing-masing mencapai 35 dan 44 persen. Titik temu antara sektor pertanian dan sektor industri terjadi pada saat GNP per kapita sekitar $\$ 350$ dengan masing-masing sumbangannya terhadap GDP sebesar 25 persen.

Pergeseran komposisi tenaga kerja berlangsung setelah berlangsungnya pergeseran struktur produksi. Pada saat
GNP per kapita $\$ 100$, komposisi tenaga kerja di sektor pertanian sangat besar yaitu sekitar 64 persen dari total tenaga kerja. Sedangkan komposisi tenaga kerja yang bekerja di sektor-sektor industri dan jasa masing-masing baru 10 dan 26 persen. Dengan meningkatnya GNP per kapita, komposisi tenaga kerja di sektor pertanian semakin menurun sedangkan komposisi tenaga kerja yang bekerja di sektor industri dan jasa semakin meningkat. Ketika GNP perkapita $\$ 1000,00$, komposisi tenaga kerja yang bekerja di sektor pertanian tinggaal 23 persen, sedangkan komposisinya di sektorindustri menjadi 33 persen dan sektor - jasa sebesar 44 persen. Titik temu antara komposisi tenaga kerja yang bekerja di sektor pertanian dan sektor industri terjadi ketika GNP per kapita sekitar $\$ 680$.

Struktur produksi Indonesia yang diamati sejak tahun 1971 sampai tahun 1988 mengalami pergeseran (lihat Gambar Struktur Produksi). Pada tahun 1971, peranan sektor primer dalam GDP sangat dominan dengan persentasenya hampir 60 persen, sedangkan sektor sekunder berperanan kecil dengan persentasenya hanya kurang dari 10 persen. Sumbangan sektor primer tersebut terus menurún dari tahüne tahun berbarengan dengan semakin meningkatnya peranan sektorindustri. Pada tahun 1988 sumbangan sektorprimer sekitar 35 persen dan sektor sekunder berperan

6)Lihat Kuznets, Simon, "Quantitative Aspects of the Economic Growth of Nations", Economic Development and Cultural Change, seri dari 10 artikel, '1956-1957.

7) Lihat Chenery, Hollis B., "Pattems of Industrial Growth", American Economic Review, 50 : 624-54, 1960. Penelitian ini kemudian direvisi oleh Chenery, H.B dan Syrquin, M. dalam "Patterns of Development, 1950-1970", Oxford University Press, London, 1975. 
sekitar 25 persen. ${ }^{8)}$

Berbeda dengan struktur produksi, komposisi tenaga kerja tidak mengalami perubahan yang berarti selama dua dekade terakhir.Pada tahun 1971, persentase tenaga kerja yang bekerja di sektor primer sangat tinggi, hampir70persen. Persentase tersebut secara perlahan menurun dan pada tahun 1988 menjadi 55 persen. Menurunnya persentase tenaga kerja di sektor primer tersebut ternyata sedikit sekali yang diserap oleh sektor sekunder. Persentase tenaga kerja di sektor sekunder hanya meningkat sedikit, dari 9 persen pada tahun 1971 menjadi 12 persen pada tahun 1988. Di luar harapan, sektor tersier mengalami pertumbuhan yang cepat dalam persentase tenaga kerja, dari 24 persen di tahun 1971 menjadi 36 persen pada tahun $1988 .{ }^{9)}$

Pergeseran strukturekonomi tersebut ternyata tidak secara dengan sendirinya diikuti dengan re-alokasi tenaga kerja dari sektor pertanian ke sektor industri yang memerlukan pengetahuan yang lebih tinggi. ${ }^{10)}$ Mereka yang bekerja di sektor pertanian bergeser ke sektor jasa yang memerlukan tingkat pengetahuan dan keterampilan yang tidak tinggi.Gejala munculnya pedagang asongan, pedagang kecil kaki lima, kuli-kuli bangunan merupakan gejala yang menyertai perluasan sektor jasa tersebut. Perluasan sektor jasa semacam itu memberikan pengaruh yang sangatterbatas bagi pembangunan ekonomi. Perluasan sektor-sektor dengan tingkat produktivitas dan efiensi yang lebih tinggi diperlukan dalam pembangunan ekonomi.

Dalam periode tinggal landas akan terjadi suatu transformasi berpengaruh terhadap proporsi tenaga kerja menurut tingkat pendidikan. Anggaran yang digunakan adalah bahwa perubahan koefisien industri menurut tingkat pendidikan berlangsung menurut suatu pola yang konsisten sejalan dengan proses pembangunan ekonomi dan perubahan struktural. Data yang digunakan berasal dari negara-negara Tepian Pasifik (Pacifik Rim) yaitu Jepang, Korea, Hong Kong, Muangthai, Filipina, Singapura dan Indonesia tahun 1960-1987.

Pola keterkaitan antara pembangunan pendidikan dan pertumbuhan ekonoini dapat digambarkan sebagai berikut. Proporsi tenaga kerja yang berpendidikan dasar atau kurang akan semakin berkurang dengan meningkatnya pembangunan ekonomi dan mereka yang berhasilmenamatkan pendidikanmenengah dan pendidikan tinggi akan semakin meningkat. Tenaga kerja yang tidak memperoleh pendidikan akan semakin meningkat pada awal pembangunan ekonomi, tetapi kemudian semakin menurun pada tahap pembangunan yang lebih tinggi bersamaan dengan

8) Lihat Boediono dan Abas Gozali, "Pendidikan dan PergeseranStruktural DalamPeriode Tinggal Landas", makalah disajikan pada Lustrum Ke-7 Fakultas Ekonomi, Universitas Gadjah Mada, Yogyakarta. Proyeksi datanya lihat Boediono, "Menjelang PembangunanJangkaPanjang Duapuluh Lima Tahun Kedua, 1993-2018 (Model Empat Sektor)", Pusat Informatika, Balitbang Depdikbud, Januari 1990.

9) Data diolah dari Biro Pusat Statistik menggunakan klasifikasi sektor primer, sekunder, dan tersier. Mubyarto mengutip data Arsyad Anwar dalain "Menerawang Masa Depan Pertanian Indonesia", Hutan, Perladangan dan Pertanian Masa Depan, P3PK, UGM, Yogyakarta, 1991, menggunakan klasifikasilain mempunyai angka yang berbeda. Demikian juga Sukartawi dalam "Reorientasi Pendekatan Pembangunan Pertanian, Prisma, nomor 11, tahun XX, Nopember 1991.

10) Mengenai industrialisasi di Indonesia, lihat juga HalHill, InvestasiAsing dan Industrialisasi di Indonesia, penerbit LP3ES, Jakarta, 1991. 
meningkatnya jumlah mereka yang berpendidikan dasar, menengah dan yang berpendidikan tinggi. Koefisien kumulatifnya diharapkan akan meningkat dengan meningkatnya pembangunan. Pola perubahan ini diharapkan akan berlangsung bersamaan dengan meningkatnya pembangunan nasional di masa depan (lihat GambarPola StrukturPendidikan Angkatan Kerja.).

Komposisi tenaga kerja menurut pendidikan di Indonesia pada akhir tahun 1980-anmenunjukkan bahwajumlah tenaga kerja yang tidak bersekolah sebesar 53 persen, mereka yang berpendidikan dasar. sebesar 34 persen, mereka yang berpendidikanmenengah sebesar 11 persen, mereka yang berpendidikan universitas sebesar 2 persen. Pengalaman negaranegara yang telah mengalaimi tinggal landas (misalnya Jepang, Korea dan Singàpura) menunjukkan suatu komposisi tenaga kerja menurut tingkat pendidikan yang berbeda dari negara-negara yang sedang berkembang.

Proporsi merekayangberpendidikan menengah dan dasar di negara yang sudah melakukan tinggal landas biasanya lebih besar daripada mereka yang tidak berpendidikan dan yang berpendidikan tinggi. Pola yang demikian terjadi karena dalam masa tinggal landas, diperlukanlebih banyak tenaga kerja yang berpendidikan menengah dan dasar sebagai pelaksana langsung pembangunan.

Berdasarkan pola keterkaitan antara pendidikan dan pertumbuhan ekonomi, dapat diamati behwa agar Indonesia memasuki proses tinggal landas maka proporsi tenaga kerja yang berpendidikan menengah dan dasar harus ditingkatkan seperti pola proporsi tenaga kerja negara yang telah melakukan tinggal landas. Pada akhir Pembangunan Jangka Panjang 25 Tahun Kedua, proporsi tenaga kerja yang tidak berpendidikan diduga perlu dikurangi dari 53 persen pada tahun 1990-an menjadi 11 persen. Mereka yang berpendidikan dasar dan menengah masing-masing ditingkatkan dari 34 persen dan 11 persen pada tahun 1990-an berturut-turut menjadi 52 persen dan 32 persen. Adapun mereka yang berpendidikan tinggi ditingkatkan dari 2 persen menjadi 5 persen, dengananggapan tingkat pertumbuhan ekonomi 7 persen (lihat Gambar Angkatan Kerja Tahun 2000an). ${ }^{11)}$

Apabila diamati secara lebih terperinci lagi, tenaga kerja yang tidak berpendidikan akan lebih terpusat bekerja pada sektor pertanian. Mereka yang tidak berpendidikan ini dalam sektorindustri jauh lebih kecil jumlahnya, sementara dalam sektor jasa hampir tidak ada. Mereka yang berpendidikan dasar pada ke tiga sektor tersebut kelihatannya diperlukan dalam jumlah yang lebih besar. Sementara itu mereka yang berpendidikan menengah diperlukan dalam jumlah yang besar lagi untuk bekerja pada sektor industri dan jasa. ${ }^{12)}$

\section{Pendidikan dan Latihan}

Pendidikan dilihat dari dimensi waktu dapat dibedakan dalam jangka

11) Lihat makalah-Boediono dan Luis Crouch, EducationalComposition inthe Labor Foree :EvidenceforIndonesia's Future FromOther Pacific Rim Countries, Center for Informatics, Office of Research and Development, Ministry of Education and Culture, July 1990.

12). Lihat Boediono, Yudo Swasono, Luis Crouch, Margaret Andrews, Hank Healey, An Approach for Human Resources Supply and Demand Projections in Indonesia, September 1990. 
pendek, jangka menengah dan jangka panjang. Pendidikan dalam jangka pendek merupakan gejala pendidikan itu sendiri di mana peningkatan pengetahuan dan pembentukan watak anak didikmerupakan tujuanutamanya.Pendidikan dalam jangka menengah merupakan gejala ekonomi yang mempersoalkan keterkaitan antara hasil pendidikan dengan kebutuhan angkatan kerja sehingga pemilikan pengetahuan dan keterampilan merupakan hal yang paling utama. Sedangkan pendidikan dalam dimensi waktu jangka panjang merupakan gejala kebudayaan di mana penerusannilainilai dari satu generasi ke generasi berikutnya merupakan tujuan pokoknya. Pembedaan pendidikan dalam dimensi waktu ini tidak dapat dilihat sécara fisik dalam proses pendidikan, karena proses pendidikan berlangsung secara simultan dalam ke tiga dimensi waktu tersebut. Membicarakan pendidikan dalam periode tinggallandas adalahmembahas pendidikan sebagai gejala ekonomi dan gejala kebudayaan.

Pendidikan dan latihan diperlukan dalam periode tinggal landas agaknya terpusat pada tiga permasalahan utama sebagai berikut. Pertama, meńingkatkan pengetahuan dn keterampilan mereka yang sudah keluar dari lembaga pendidikan (lulusan maupun putus sekolah) sehingga dapat memasuki lapangan kerja. Kedua, meningkatkan pengetahuan dan keterampilan bagi mereka yang tertinggal oleh kemajuan ilmu pengetahuan dan teknologi tenaga kerja yang sudah bekerja. Ketiga, menyiapkan generasi yang akan datang agar mampu berperan serta secara aktif dalam pembangunan. Dua permasalahan yang disebutkan terdahulu berkaitan dengan permasalahan yang dihadapi dalam masa kini; sedangkan yang disebutkan terakhir menyangkut permasalahan yang dihadapi dalam masa depan.

Dalam mencari penjelasan terhadap ancaman tentang rendahnya produktivitas dan mutu tenaga kerja di Amerika Serikat pada akhir abad ke 20 dan di masa depan, Komisi Produktivitas dari Massachussetts Institute of Technology memberikanuraian sebagai berikut. ${ }^{13)}$ Banyak orang percaya bahwa Amerika memprodusir lebih rendah daripada Jepang atau Jerman karena tenaga kerja Amerika telah menjadi terlalu mewah, malas dan aman. Komisi menemukan bahwa pangkal persoalannya bukan terletak pada pudamya atau melemahnya nilai dasar Amerika dankemampuannya, tetapi dalam lembaga-lembaga yang mendidik orang Amerika untuk bekerja.

Mengenai pola pendidikan dan latihan yang diperlukan untuk meningkatkan produktivitas industri, Komisi membedakan dua macam pola. Termasuk dalam pola A adalah negaranegara seperti Amerika Serikat, Swedia dan Inggris, di mana lembaga pendidikan formal memberikan hampir seluruh keterampilan khusus yang diperlukan untuk bekerja, dan pelatihan di tempat kerja memberikan sedikit lebih banyak daripada instruksi yang berkaitan dengan tugas yang segera harus dilaksanakan. Pola B yang dianut negara-negara seperti Jepang dan Jerman Barat, sangat bersandar pada pelatihan di tempat kerja (on-the-job training) untuk mengembangkan keterampilan khusus danumum.Pertanyaan adalah apakah alur yang berbeda akan

13) Lihat Michael L.Dertouzos, Richard K.Lester, dan Robert M.Solow, Made inAmerica, The Massachussetts Institute of Technology, Cambridge, Massachussetts, 1989. 
berpengaruh terhadap perbedaan produktivitas? Komisi sampai pada suatu kesimpulan bahwa pola $\mathrm{B}$, pelatihan di tempat kerja, ternyata lebih mudah menghasilkan tenaga kerja dengan fleksibilitas dan keterampilan yang diperlukan untuk menjawab perubahanperubahan teknologi dan pasar yang sangat cepat dan tidak dapat diduga. Meskipun demikian, seperti kasus di Swedia yang termasuk dalam pola $A$, produktivitas tenaga kerjanya tinggi dan pendapatan perkapita-nya termasuk yang paling tinggi di dunia.

Di Amerika Serikat dan negara lain yang termasuk dalam pola $\mathrm{A}$, sekolah atau pendidikan formal merupakan lembaga utama yang mengajarkan keterampilan. Kegagalan dan transisi struktural dari sekolah menengah ke dunia kerja mengakibatkan kelemahan keterampilan dibandingkan dengan tenaga kerja dari Jepang dan Eropa. Meskipun demikian, kombinasi keterkaitan yang ketat dengan pengusaha lokal dan kebijaksanaan yang fleksibel dalam program pembiayaan, materipelajaran dan carapenyampaian telah menyebabkan "community college" sangat efektif dalam penyiapan tẹnaga kerja untuk memasuki lapangan kerja.

Di Jerman hampir semua anak usia 16 tahun memasuki pekerjaan magang (apprenticeship) yang ditawarkan dalam 400 jabatan. Bagi tiap-tiap pelatihan, kurikulum disusun bersama dengan pejabat pemerintah, perkumpulan pengusaha, dan serikat kerja. Kurikulumnya disesuaikan secara teratur agardapat memenuhi tuntutan perubahan teknologi. Ujian nasional memberikan sertifikat terhadap mereka yang berhasil menyelesaikan pekerjaan magang (apprenticeship) tersebut. Di Jepang pendidikan dan latihan bagi pekerjaan khusus dan promosi dalam suatu jenjang karier direncanakan dan dilakukan oleh perusahaan individual dan tidak diorganisir oleh program nasional.

Terdapat banyak sekali bukti bahwa sistem pendidikan dan latihan menggunakan pola $B$ di negara-negara Jepang dan Jerman Barat ternyata mempunyai kelebihan untuk menghasilkan tenaga kerja yang terampil dan fleksibel. Ada alasan juga untukmempercayai bahwa pelajaran keterampilan di dalam bengkel kerjalebih diutamakan daripada di sekolah. Keunggulanpendekatanmenggunakanpola B disebabkan karena keterampilan yang dikembangkan bersifat lebih luas dan relevan untuk memenuhi kebutuhan masa kini dan masa depan perusahaan. Ada juga bukti bahwa keterampilan yang lebih luas dan fleksibel mempunyai pengaruh terhadapprestasi industri. Perbedaan latihan kerja di perusahaan terhadap prestasi kerja dapat diamati bukan hanya bagi pekerja kasar tetapi juga bagi para teknisi dan insinyur.

Pelatihan kembali atau retraining bagi tenaga produksi, insinyur, teknisi, dan manajer yang memerlukan untuk mempelajari keterampilan baru pada waktu perusahaannya mengalami transformasi ekonomi dan telnologi. Pelatihan kembali ini juga diperlukan bagi mereka yang belum bekerja yang memerlukan keterampilan dan pekerja baru. Tidak satupun dari keduanya dapat dikerjakan dengan baik oleh Amerika Serikat. Di Amerika Serikat tenaga kerja yang sudah tua akan dipecat (atau tidak dipekerjakan kembali) untuk memberikan - jalan kepada tenaga kerja baru yang memiliki keterampilan baru. Sebaliknya di Jepang dan Jerman Barat, pola pelatihan di tempat kerja dan rotasi memberikan jalan pelatihan kembali secara teratur bagi tenaga 
kerja di semua jenjang. Rotasi menciptakan keterampilan yang beraneka ragam, tenaga kerja yang fleksibel siap berubah dengan menciptakan suatu kondisi pikiran untuk belajar.

Mengenai sistem pendidikan semacam apa yang diperlukan dalam tahap pembangunan jangka panjang 25 tahun kedua, Soedjatmoko memberikan gambaran sebagai berikut. ${ }^{14)}$ Sudah barang tentu gambaran tersebut bukan merupakan jawaban yang lengkap. Sistem pendidikan yang diperlukan di masa yang akan datang, lebih menyangkut "spirit", jiwanya pendidikan. Pertama, cara mendidik harus mengakui dan menerima individualitas setiap anak didik, danmencoba merangsang dia untuk berpikir sendiri, secara kritis dan kreatif. Selanjutnya yang häas diutamakan ialah bukan soal alih pengetahuan, melainkan peningkatan (learning capacity), kemampuan belajar bangsa, dan belajar seumur hidup tanpa hentinya.

Adapun ciri-ciri dankemámpuanlain yangdigambarkannya adalah bahwa sistem pendidikan perlu disesuaikan lebih banyak pada keperluan usaha industrialisasi, yaitu proporsi insinyur dan ilmuwan untuk mengisi keperluan dalam usaha industrialisasi. Selanjutnya diuraikan juga bahwa selain peningkatan jumlah insinyur dan pakar di bidang ilmu murni, keaneka ragaman di bidang ilmu dan teknologi perlu dikembangkan.

\section{Soedjatmoko selanjutnya} memberikan penjelasan bahw ilmu pengetahuan dan teknologi yang paling besar dampaknya atas perkembangan masyarakat dan keadaan manusia dalam tahap pembangunan yang akan datang, ialah bidang boiteknologi, mikroelektronika dan informatika, dan juga teknologi bahan (material technology). Disiplin-disiplin: ilmiah yang melandasi ketiga bidang teknologi ini ialah solid state physics dan matematika untukbidang mikroelektronika dan biologi mikro serta genetika untuk bioteknologi. Iskandar Alisyahbana mengatakan -bahwa ada empat bidang teknologi yang telah dan' akan terus menentukan perkembangân ilmu pengetahuan dan teknologi di Indonesia. Berdasarkan urutan laju dan prioritas pengembangannya, bidang-bidang itu adalah: teknologi informasi, bioteknologi, teknologi penerbangan dan ruang angkasa, serta teknologi sumber dya energi -termasuk di antaranya teknologi nuklir. ${ }^{15}$ )

Secara singkat, permasalahan utama dalam era tinggal landas berkaitan dengan permasalahan masa kini yaitu mereka yang sudah lepas dari lembaga pendidikan tetapi belum bekerja dan mereka yang sudah bekerja tetapi tertinggal dari kemajuaniptek, serta berkaitan dengan masa depan yaitu penyiapan generasi muda di masa depan. Adapun mengenai sistem pendidikan di masa depan agaknya berkaitan dengan: (1) pembentukan "spirit",jiwanya pendidikan; (2) peningkatan kemampuaan belajarseumur hidup; dan (3) penyesuaian pada keperluan usaha industrialisasi. Pola pendidikan dan latihannya agaknya perlu disesuaikan dengan daya serap lingkungan dan tahap perkembangan pembangunan.

\section{Pendidikan dan Pembangunan}

Salah satu keberhasilan yang sangat

14) Lihat Soedjatmoko, "Manusia Indonesia Menjelang Abad ke-21 dan Persiapannya", Prospek, nomor 1, volume 2, 1990.

15) Lihat Prof. Dr. Iskandar Alisyahbana, "Wajah Iptek Indonesia di Masa Depan", dalam Periskop ' 92 majalah Editor, nomor 16, tahun V, 4 Januari 1992. 
mengesankan pembangunan pendidikan adalah terbitnya Undang-undang Nomor 2 Tahun 1989 tentang Sistem Pendidikan Nasional. Terbitnya Undang-undang ini dilengkapi dengan Peraturan Pemerintah (PP) yang menyertainya yaitu PP No. 27 Tahun 1990 Tentang Pendidikan Dasar, PP No. 28 Tahun 1990 Tentang Pendidikan Dasar, PP No. 29 Tahun 1990 Tentang Pendidikan Menengah, PP No. 30 Tahun 1990 Tentang Pendidikan Tinggi, PP No. 72. Tahun 1991 Tentang Pendidikan Luas Biasa, PP No. 73 Tahun 1991 Tentang PendidikanLuarSekolah, PPNo.38Tahun 1992 Tentang Tenaga Kependidikan, PP No. 39 Tahun 1992 Tentang Peranserta Masyarakat Dalam Pendidikan Nasional. Undang-undang No.4Tahun 1990Tentang Serah Simpan Karya Cetak dan Karya Rekam, PP No. 70 Tahun 1991 Tentang Pelaksanaan Undang-undang No. 4 Tahun 1990 Tentang Serah Simpan Karya Cetak dan Karya Rekam, dan Undang-undang No. 5 Tahun 1992 Tentang Benda Cagar Budaya.

Diberlakukännya Undang-undang Nomor 2 Tahun 1989 tentang Sistem Pendidikan dan Peraturan Pemerintah yang menyertainya maka pembangunan pendidikan dalam periode tinggal landas akan diselenggarakan dalam suatu "aturan permainan" yang lebih mantap. Dengan perkataanlain, Undang-undang No.2Tahun 1989 dengaan Peraturan Pemerintah yang menyertainya merupakan lạdasan pembangunan pendidikan di masa depan.

Pembangunan pendidikan dewasa ini agaknya harus dipandang sebagai gejala permintaan atau demand phenomena yaitu mempersoalkan untuk apa lulusan itu dihasilkan. Dengan perkataan lain, pembangunan pendidikan agaknya perlu dipandang dalam kaitannya dengan pembangunan ekonomi dan teknologi pada khususnya dan pembangunan nasional pada umumnya. Setiap tahap pembangunan pendidikan memerlukan penekananpenekanan khusus sesuai dengan tuntutan lingkungan pembangunan yang berlangsung pada periode tertentu. Dalam kasus kaitan pembangunan pendidikan dengan pembangunan ekonomi di Korea dapat digambarkan sebagai berikut: ${ }^{16}$ Sampai dengan tahun 1975, pembangunan nasional di Korea ditekankan pada pembangunan industri pertanian yang kurang memerlukan keterampilan. Dalam periode wajib belajar sekolah dasar dan sekolahmenengah tingkat pertama. Struktur kurikulumnya ditekankan pada "lifecontered curriculum" atau real things oriented program". Dalam periode tahun 1965 hingga 1975, pembangunan ekonomi ditekankan pada "labor intensive industry" seperti misalnya industri tekstil, sepatu, pengalengan dan konstruksi. Dalam periode tersebut struktur kurikulumnya bersifat "discipline contered curriculum" sehingga misalnya fisika, kimia, biologi diajarkan sebagai suatu disiplin ilmu yang terpisah. Pada periode 1975 hingga 1985, perekonomian ditekankan pada "heavy chemical industry" seperti misalnya manufakturing, pembangunan kapal, pupuk dan semen yang memerlukan keterampilan kelas menengah. Perbandingan jumlah sekolah umum dengan sekolah kejuruan adalah sebesar 70 berbanding 30 . Pada tahun 1985 dàn masa mendatang, perekonomian ditekankan pada "knowledge intensive in-

16) Diskusidengan Dr, Jong Ha Han, direktur Korean Education Development Institute (KEDI), tanggal 12 Maret 1993. KEDI adalah lembaga di luar Kementrian Pendidikan Korea yang merupakan perumus kebijakan pendidikan di Korea. 
dustry" seperti misalnya komputer, robatik, telekomunikasi, space science dan industri nuklir. Struktur kurikulumnya berorientasi pada "science and technology teaching in a social context". Jumlah sekolah umum dibanding dengan sekolah kejuruan direnacanakan akan sebanding. Dari pengalaman Korea tersebut dapat dilihat dengan jelas keterkaitan kurikulum pendidikan dengan tingkat pembangunan ekonomi dan teknologinya.

Meskipun demikian mengingat investasi di bidang pendidikan merupan suatu proses berjangka panjang, maka pembangunan pendidikan tersebut perlu dilaksanakan berdasarkan suatu ideologi. Dalam pembangunan pendidikan di Indonesia, landasanídeologitersebutdinyatakan dalam amanat Pembukaan UUD 1945 "..memajukan kesejahteraan dunia...". Amanatini menunjukkan secarajelas bahwa orientasi pendidikan adalah untuk menghapuskan kemiskinan atau meningkatkan taraf hidup, meningkatkan mutu pendidikan atau meningkatkan kecerdasan, serta melaksanakannya sesuai dengan perkembangan ilmu pengetahuan dan teknologi. Dengan demikian pembangunan pendidikan dilaksanakan sesuai dengan tahap-tahap pembangunan ekonomi dan teknologi pada khususnya dan pembangunannasional padaumumnya. Pembangunan Pendidikan di Tepian Pasifik

Kemajuan pendidikan di Indonesia dalam lingkungan kemajuan pendidikan di - negara-negara Tepian Pasifik (pacifik Rims) dapat digambarkan sebagai berikut. ${ }^{17}$ ) Perbandingan anak usia sekolah dasar terhadap pendidikan usia sekolah dasar di Indonesia di antara negara-negara Singapura, Malaysia, Thailand, Hong Kong dan Korea menunjukkan gejala yang sebanding (lihat Grafik Primary Gross Enrollment Ratios). Keberhasilan program SD Inpres kiranya merupakan faktor yang berpengaruh terhadap pencapaian prestasi tersebut, dengan anggapan adanya kesamaan mutu sekolah dasar di antara negara-negara tersebut.

Pada tingkatsekolahlanjutan tingkat pertama dan sekolah menengah atas, data time series tahun 1960-1990 yang tersedia menunjukkan bahwa Indonesia betada pada derajat yang paling rendah, di mana Hong Kong dan Korea berada di puncaknya (lihat. Grafik Secondary Gross Enrollment Ratios). Program wajib belajar pendidikan dasar 9 tahun agaknya merupakan upaya untuk mengatasi permasalahan ini. Sekali lagi dengan catatan tentang mutu sekolah lanjutan tingkat pertama.

Dalam kaitannya dengan permasalahan ketenaga kerjaan, dapat diamati bahwa prensentase tenaga kerja yangberpendidikan tingkatsekolahlanjutan pertama dan sekolah menengah menunjukkan bahwa keadaan Indonesia pada tahun 1989 masih iberada di bawah Hong Kong pada tahun' 1960 dan Korea pada tahun 1970 (lihat Grafik Percentage of LaborForce with Secondary Education). Keadaan Indonesia pada tahun 1989 memangagak sulit diperbandingkan dengan

17) Perbandingan kemajuan pendidikan di Indonesia dengan negara-negaralain di Tepian Pasifik dilakukan untuk memperluas wawasan pembangunan pendidikan di Indonesia. Lihat Boediono, Walter McMahon, dan Don Adams (eds.). Education, Economic, and Social Development, Center for Informatics, Office of Educational and Cultural Research and Development, Ministry of Education and Culture, Jakarta 1992. Lihat juga Walter McMahon and Boediono, Education and the Economy, Center for Informatics, Office of Educational and Cultural Research and Development, Ministry of Education and Culture, Jakarta 1992. 
Korea pada tahun 1970, karena pada tahun. 1989 pendapatan per kapita Indonesia sekitar US\$540 sedangkan Korea pada tahun 1970 masih sekitar \$243. Hal ini mungkin mencerminkan suatu keadaan bahwa upaya peningkatan pendidikan tenaga kerja di Indonesia agaknya sedikit banyak dapat ditingkatkan dengan kecepatan yang lebih tinggi daripada Korea.

Rata-rata tenaga kerja Indonesia berada di bawah Singapura, Malaysia, Korea, Taiwan. Bahkan rata-ratapendidikan tenaga kerja Indonesia tersebut berada di bawah rata-rata pendidikan negara-negara Tepian Pasifik (lihat Grafik Average Years of Education of Labor Force). Lama waktu rata-rata pendidikan tenaga kerja di Indonesia ini agaknya juga menunjukkan derajat yang paling rendah dibandingkan dengan negara-negara Tepian Pasifik lainnya (lihat Grafik Rated Quality of the Labor Force).

Adapun presentasi Penghasilan Nasional yang dialokasikan untuk sektor pendidikan di Indonesia juga masih paling rendah dibandingkan dengan rata-rata Tepian Pasifik maupun masing-masing negara Tepian Pasifik (lihat Grafik Percent of GDP Spent on Education): Dalam persentase dari Gross National Product, pengeluaran Pemerintah Pusat tidak jauh dari serendah Pakistan. Tetapi pada tingkat 2,15 persen dari GDP pada tahun 1988, tingkat investasi pendidikan oleh PemerintahPusatmasih tetapyang terendah di antara negara-negara ASEAN dan negara-negara TepianPasifik (pacifikRim), di mana tingkat rata-ratanya sebesar 4,2 persen. Tingkat investasi dalam pendidikan ini hanya sebesar kira-kira separuh dari 4 persen dari GNP yang telah diinvestasikan Jepang dalam tahun 1960 pada saat tinggal landas Jepang menuju ke tingkat pertumbuhan yang lebih cepat, sekitar 4,01 persen dari GNP yang telah diinvestasikan Pemerintah Pusat Thailand, dan kira-kira sepertiga dari yang diinvestasikan oleh Pemerintah Pusat Malaysia dalam periode 1972-1975. Ketika Korea tinggal landas menuju ke pertumbuhan ekonomi yang lebih pesat pada tahun 1960-an, anggaran Deprtemen Pendidikan sebesar 2,6 persen dari GNP atau sebesar 15,2 persen dari total pengeluaran pemerintah, atau sekitar 150 persen dari tingkat investasi di Indonesia pada tahun $1988 / 89 .{ }^{18)}$

Tingkat investasi dalam kapital fisik telah meningkat secara tajam dari 11,7 persen dari GNP pada tahun 1969 (awal Pelita I) menjadi 23,6 persen dari GNP pada paling sedikit akhir Repelita IV, yaitú yang kedua setelah Singapore dalam di antara negara-negara ASEAN. Tetapi, tingkat investasi dalam pendidikan yang diperlukan untuk mendukung proses industrialisaasi dan untuk mendukung pemerataan hanya berlangsung sangat lambat. Dengan. 10 persen dari anggaran Pemerintah Pusat pada tahun 1988, angka ini yangterendah dari seluruhnegara-negara ASEAN dan negara-negara Tepian Pasifik (Pacifik Rim), dimana rata-rata keseluruhannya sebesar 18,6 persen. ${ }^{19}$

18) Lihat Boediono dan Walter McMahon, "Education, Structural Change, and Investment in Indonesia", dalam Boediono, Walter McMahon, and Don Adams (eds.), Education, Economic, and Social Development (Second 25 Year Development Plan and Sixth 5 Year Development Plan Background Papers and Goals, Center for Informatics, Office of Research and Development, Ministry of Education and Culture, Jakarta 1992.

19) Lihat "Rancangan Rencana Pembangunan Lima Tahun VI Pendidikan dan Kebudayaan", Biro Perencanaan, Departemen Pendidikan dan Kebudayaan, Jakarta 1993. 


\section{Penutup}

Pembangunan pendidikan di masa depan akan berlangsung dalam periode tinggal landas akan berlangsung dengan berpedoman pada Undang-undang No. 2 Tahun 1989 tentang Sistem Pendidikan Nasional dan Peraturan Pemerintah yang menyertainya.

Pembangunan pendidikandewasaini agaknya perlu dipandang sebagai gejala permintaan atau demand phenomena yang berorientasi pada permasalahan untuk apa lulusan dihasilkan. Dengan perkataan lain, pembangunan pendidikan tersebut tidak dapat dilepaskan dar lingkungan pembangunan nasional di mana proses pendidikan itu sendiri tumbuh dan dibesarkan. Setiap tahapañ pembangunan memerlukan penekanan khususnya tersendiri di bidang pendidikan sesuai dengan tuntutan pembangunan nasional padaumumnyadan pembangunan ekonomi pada khususnya.

Pembangunan pendidikan itu sendiri dalam jangka panjang harus dilaksanakan berlandaskan semacam ideologi. Ideologi yang melandasi pembangunan pendidikan adalah"...memajukan kesejahteraanumum, mencerdaskan kehidupan bangsa, dan ikut melaksanakan ketertiban dunial ...".Dengan demikian, peningkatan mutu pendidikan dilaksanakan dalam kerangka peningkatan taraf hidup sesuai dengan perkembangan ilmu pengetahuan dan teknologi.

Dalam era tinggal landas jumlah penduduk akan meningkat tetapi tingkat pertumbuhannya semakin menurun. Struktur penduduk akan menjadi semakin tua. Dengan demikian permasalahan di masa depan menyangkut juga kelompok tua.

Perubahan jumlah dan struktur penduduk tersebut-akan mempengaruhi pendidikan dalam bentuk gelombanggelombang anak didik. Gelombang anak didik masuk sekolah dasar sudah menunjukkan gejala kejenuhan (level off) pada sekitar tahun 1990-95' pada jumlah kira-kira26juta; gelombangmasuksekolah lanjutan tingkat pertama mula-mula akan meningkat tetapi kemudian menurun pada sekitartahun 2000-2005 pada jumlahsekitar 12 juta; gelombang masuk sekolahlanjutan tingkat atas akan menunjukkan gejala kejenuhan pada tahun 2005-2010 pada jumlah sekitar 12 juta; sedangkan gelombang masuk pendidikan tinggi akan meningkat dan menunjukkan gejala menurun pada tahun 2020 pada jumlah sekitar 26 juta.

Dalam periode tinggal landas tersebutdiperkirakan juga akan berlangsung pergeseran struktur ekonomi dari sektor pertanian ke sektor industri dan sektor jasa. Gejala yang dapat diamati dewasaini sektor jasa yang berkembang .adalah yang memerlukan keterampilan tingkat rendah pada lapisan masyarakat berpendapatan rendah dan menengah, seperti pedagangan asongan; pasarkaget, dan sebagainya.Pada lapisan masyarakat berpendapatan tinggi pergeseran ke sektor jasa dengan keterampilan tinggi, seperti jasa perbankan. Perkembangan di sektor industri itu sendiri tidak nampak menyolok.

Berbeda dari teori, seperti dapat diamati dalam gejala masyarakat, pergeseran strukturekonomi ini tidak dapat diikuti secara langsung oleh perubahan komposisi tenaga kerja. Suatu intervensi yang aktif harus dilakukan di bidang pendidikan dan latihan agar mereka yang bekerja di sektor pertanian dapat berangsur dialokasikan ke sektor industri dan sektor jasa dengan tidak menimbulkan goncangan yang dapat merusakkan sendi-sendi 


\section{Gambar 5: Primary Gross. Enrollment.Ratios}

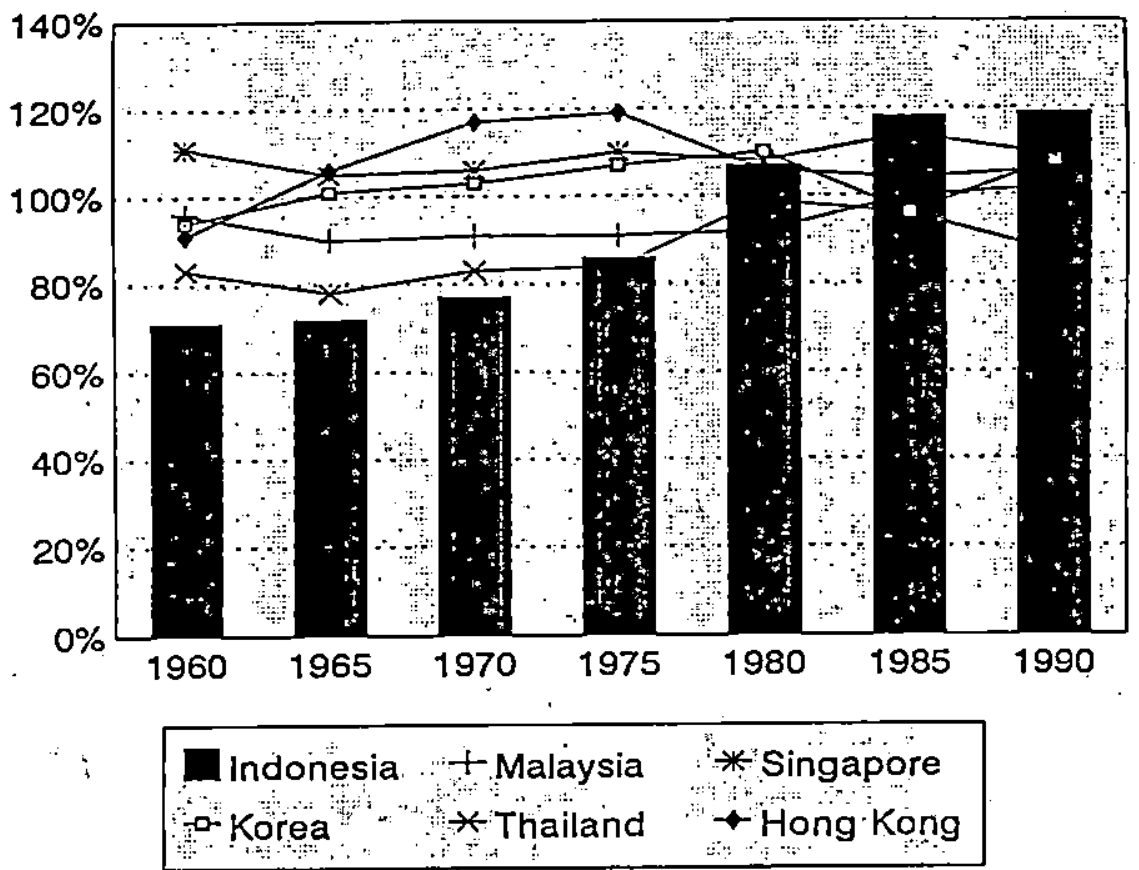

Gambar 6 : Secondary Gross Enrollent Ratios

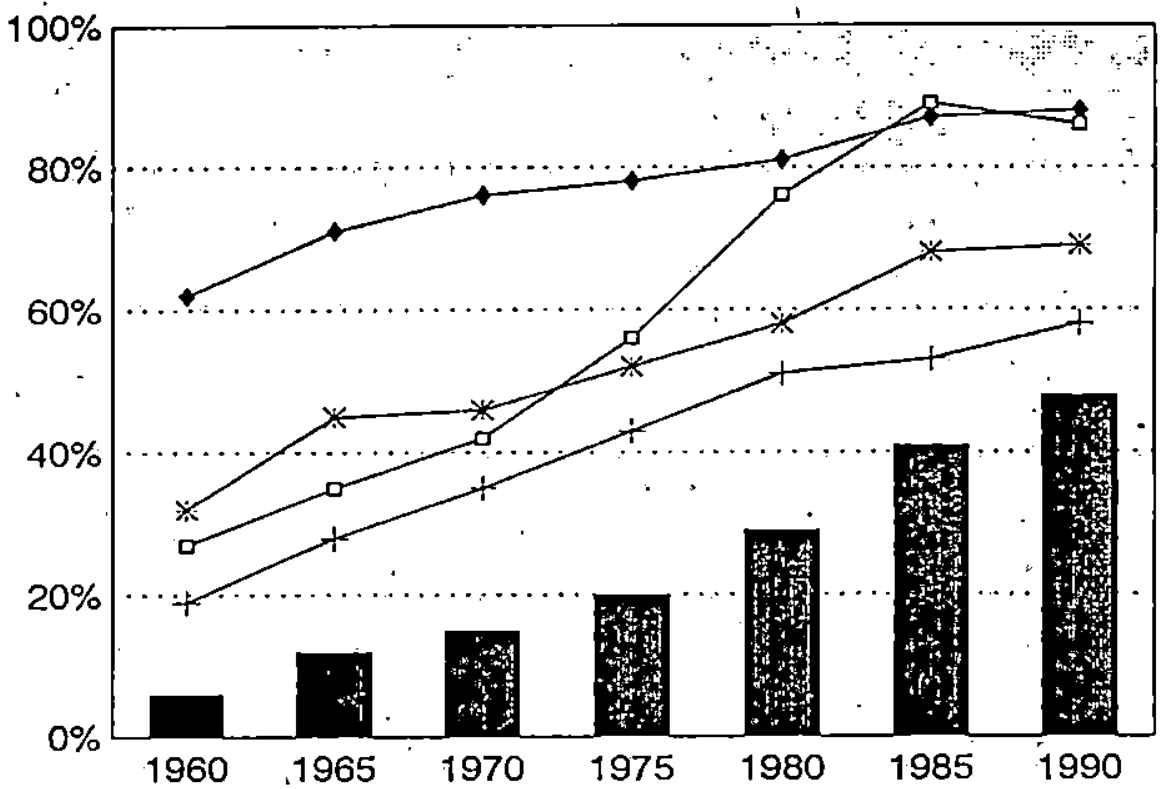

Indonesia + Malaysia $*$ Singapore - - Korea $\rightarrow$ Hong Kong 
Gambar 7 :

\section{Average Years of Education of Labor Force}

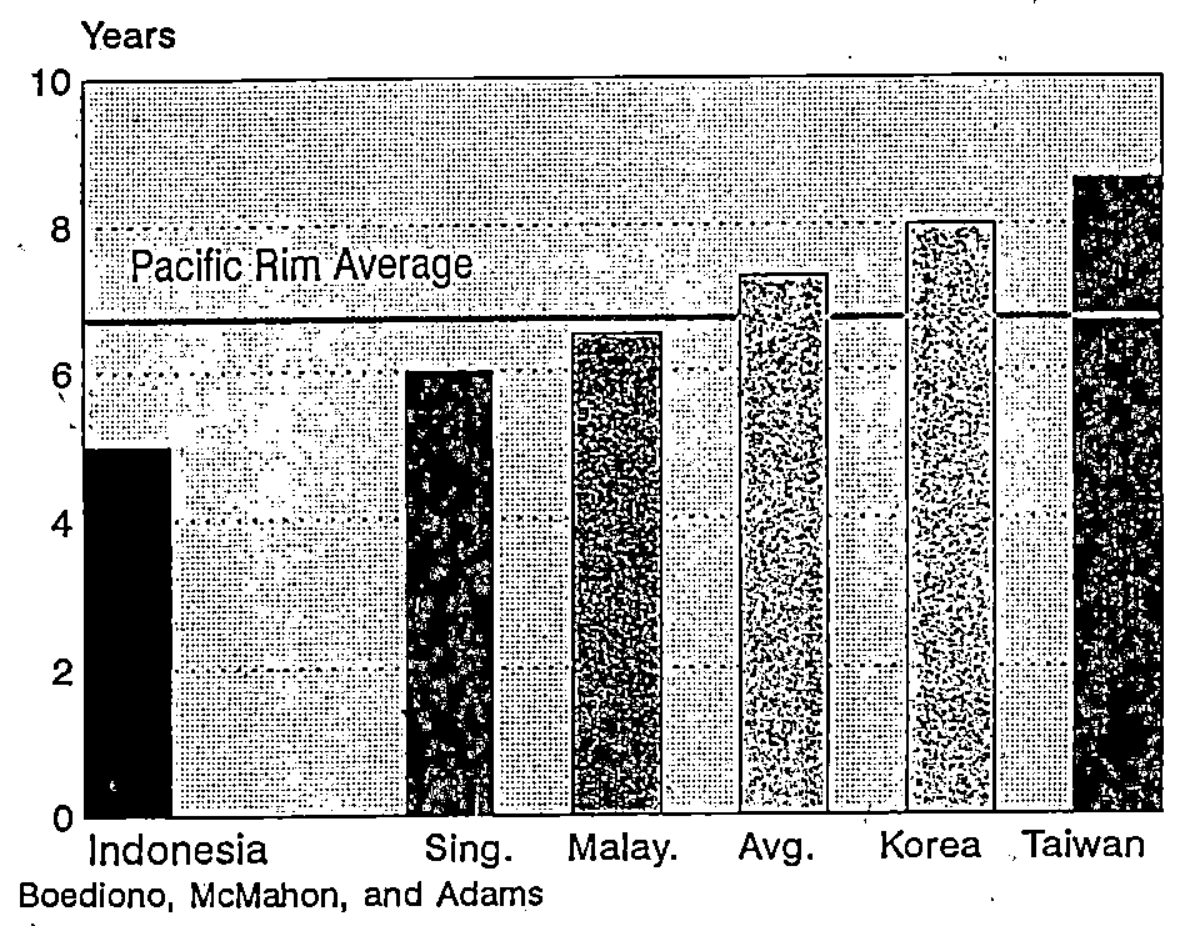

\section{Gambar 8: $\quad$ Percentage of Labor Force with Secondary Education}

\section{Percent (\%)}

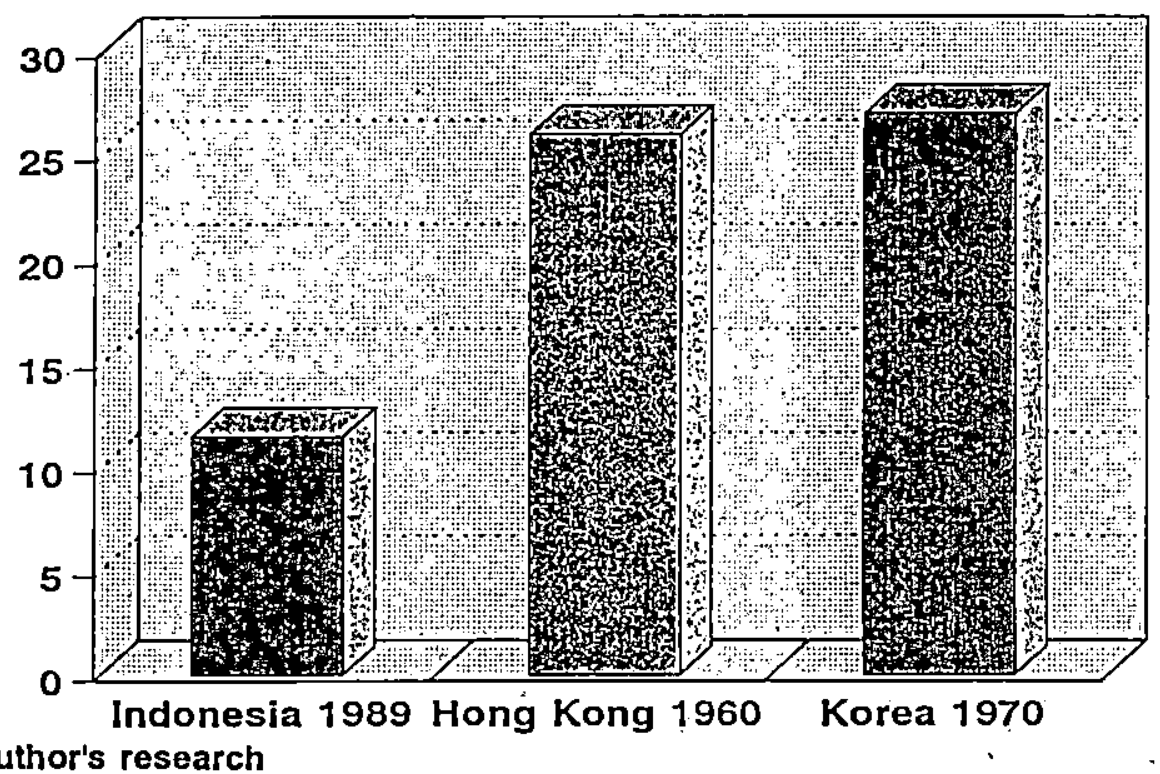




\section{Gambár 9: Rated Quality of The Labor Force} Index 0.12

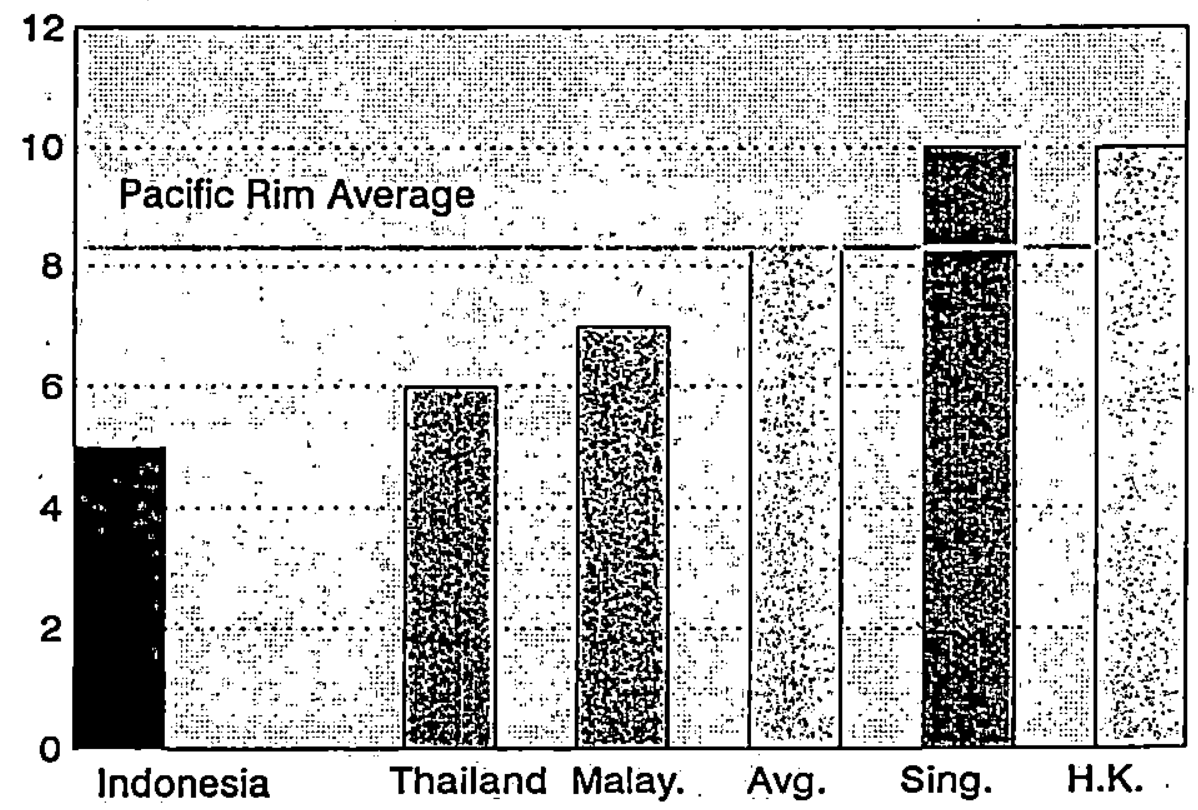

Political and Economic Risk Consultancy.

\section{Gambar 10: Percent of GDP Spent on Education}

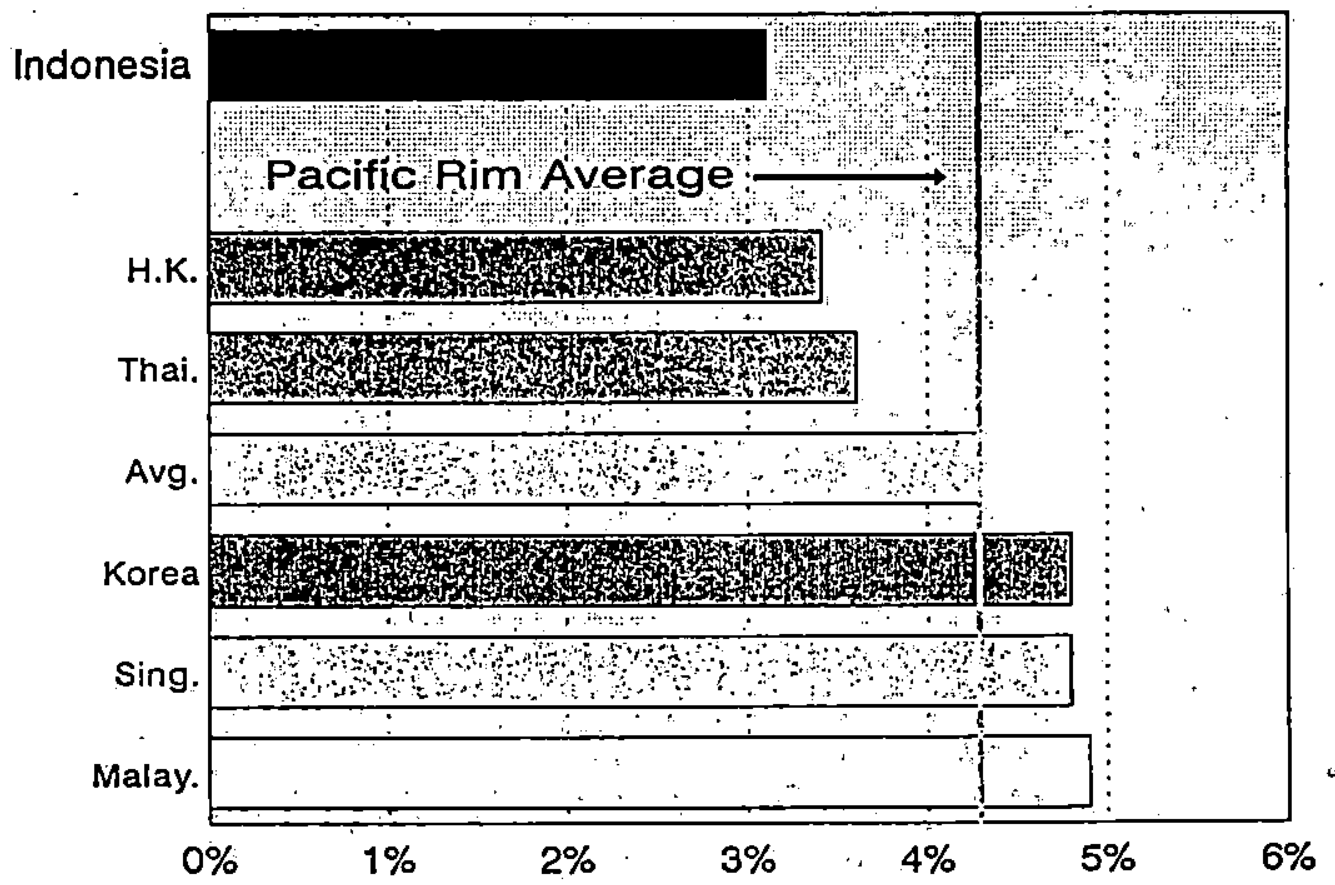

Boediono, McMahon, and Adams. 